\title{
8 Failing Careers. Men in Business in Nineteenth-century Global Trade
}

\begin{abstract}
This chapter illustrates what the ideal entrepreneur used to be and what sort of behaviour this ideal type included and what this can tell us about masculinity in the early nineteenth-century northern Baltic, among the almost exclusively male timber-trading community. By focusing not on the leading figure(s) or the most powerful men, but on those on the margins of the entrepreneurial elite, the chapter will discuss the multiple masculinities and idea of hegemonic masculinity which would have not been possible without subordinate masculinities.
\end{abstract}

In order to identify these masculinities, the chapter will discuss the language by which masculinity was created. Scholars studying female entrepreneurs have pointed out that entrepreneurial mentality can be constructed in discourse, the same way as gender. The chapter will also illustrate the importance of family and the materiality and material culture connected with businessmen, which will help to understand the experience of being a businessman.

The analysis is based on close reading of a German bookkeeper Friedrich Wilhelm Klingender's memoirs, written in the 1830s while he lived in a timber trading town of Vyborg in the northern Baltic. Through close reading of the memoirs, it is possible to argue that the masculine ideal was a strong willed, sophisticated and physically strong and virile man, whose material surroundings supported this ideal of masculinity. Entrepreneurial masculinity was essentially that of being a family man, since business was mainly family business the household was still the main production unit and the goal was to pass the business on to the next generation. The failure to establish a family and a business of his own is well documented in Klingender's memoirs.

\section{Introduction}

The entrepreneur is typically portrayed as a modern Western man. He is a person with an inborn 'entrepreneurial personality' who seizes opportunities using

\footnotetext{
Note: This work was written as part of the project Agents of Enlightenment: Changing the Minds in Eighteenth-Century Northern Europe, funded by the Academy of Finland (2017-2021) under grant number 326253.
}

¿ Open Access. (C) 2020 Ulla ljäs, published by De Gruyter. (cc)BY-NC-ND This work is licensed under a Creative Commons Attribution-NonCommercial-NoDerivatives 4.0 International License. 
his entrepreneurial mentality (Lahtinen 2018, 35-46). Scholars studying female entrepreneurs, however, have pointed out that this entrepreneurial mentality is a discursive construct, much like gender, and hence, "[discourses on] entrepreneurs are linguistic practices that create truth effects, i.e. they contribute to the practicing of gender at the very same time that they contribute to the gendering of entrepreneurial practices” (Bruni, Gherardi and Poggia 2004, 2; Hamilton 2013).

But how were the 'entrepreneur' and his identity constructed in the nineteenth century, when entrepreneurial activities were typically male-dominated? Modern business literature tends to focus on the image of the self-made man, a heroic figure adhering to the gendered stereotypes of a more recent age and largely ignores how both 'business' and what it means to be a 'man' have changed over time. In this chapter, I will illustrate how masculinity was created and maintained in global business in the nineteenth century. I will follow Herbert L. Sussman's example and use the term 'masculinity' to refer to gendered and social expectations for male behaviour (Sussman 2012, 3). Hence, I will scrutinise what it meant to be a man, how this manhood was acquired socially and culturally, and who were not eligible to become (business)men. I will highlight that not all men were allowed access to the same opportunities and rights to become a businessman.

The chapter is based on a close reading of a bookkeeper's memoirs, written in the 1830s. The writer, Friedrich Wilhelm Klingender (1781-c.1848), was a clerk who worked in the global timber industry. He was employed by several merchant houses, which imported timber from northern Baltic ports to Britain, Holland, France and Spain. In nineteenth-century Europe, there were thousands of men like Klingender - unable to establish their own business and hence, unable to climb up the social ladder. These men did not have a future in business nor in their private lives; they stayed single, lived in the small back room of the office doing their chores day after day and spent evenings alone, just like Klingender. These are men whose stories modern business histories have not told. Can we call their life-stories careers? As I will be show through Klingender's case, the expectation that one's working life should show a progression or a level of social climbing, did not necessarily come true for all men who entered the business world with such ambitions. The history of these clerks' 'careers' was shaped not only by heroic notions of masculinity, but also modulated through social class, family background, and age. There is, therefore, no single story of masculinity in the history of work and business (Kwolek-Folland 2001, 10; Craig, Beachy and Owens 2006, 1-19; Hassan Jansson, Fiebranz and Östman 2017, 127).

Klingender wrote his memoirs while he lived in Vyborg, a small town 150 kilometres north-east from St. Petersburg in the Grand Duchy of Finland. The town had a busy harbour; many of the local merchants were German descendants. 
Klingender, who was born in Cassel, worked in Hackman and company, which was at that time the leading timber export company in the Grand Duchy. The company was established in 1790 by Johan Friedrich Hackman, who was born in Bremen. During Klingender's time, the company was managed by J. F. Hackman's widow and son, J. F. Hackman jr. Before settling in Vyborg, Klingender had worked in Narva at Suthoff and company, which was another timber trading company owned by Germans, and besides these two family firms, he had been employed by St. Petersburg entrepreneurs. In his memoirs, Klingender wrote about his work, his colleagues and the people who had hired him. He never got married and the memoirs reveal the reason which he thinks is the most important - he was too poor and lacked sufficient social and economic capital to marry a woman of his class or social background. Klingender's ideas about these prerequisites for marriage reveal an essential aspect of nineteenth-century expectations of gender and work, i.e. being a married man and establishing a family was intertwined with 'proper' masculinity among businessmen.

Klingender was active in a period of fast industrialisation and globalisation of the trade. The timber industry was one of the first trades that linked the northern Baltic area to the global trade. Businessmen came to St. Petersburg, Vyborg and Narva - towns where Klingender lived and worked - from several European countries and they all shared similar social codes, religion and social capital. German businessmen settled permanently in Russia and had ties to Russia's elite as well as to the Baltic German elite living in the area (Ojala and Karonen 2006, 95-125; Schulte Beerbühl 2015, 156).

In business history, gender has become an important but somewhat onesided theme. Historians have demonstrated women's invisibility in business related sources, which has often led to thinking of women's role in the business world as a subordinate one throughout large parts of history (Simonton 2018, 112; Keskinen and Vainio-Korhonen 2018). Less interest has been shown in men and masculinities in business history and even fewer studies have focused on 'subordinate' men in business. Historiography's focus on women may result from the fact that men have historically dominated and now still outnumber women in business, and have therefore been seen to represent the norm within a gender system that has often been studied as binary and less from an intersectional point of view. The view that men's experiences in business represent the historical norm has largely been taken as self-evident and for granted, (Sussman 2012, 5) instead of questioning men's experiences as men in business. As Angel Kwoled-Folland has pointed out, in many narratives of business history “men's experience is history" (Kwolek-Folland 2001, 4; Tosh 2005, 331). 
However, as I will show in this chapter, thinking beyond the supremacy of men in business history, and using the concept of hegemonic masculinity (Connell and Messerschmidt 2005, 834) could elucidate business history in new ways.

\section{“To Assist my Memory" - Klingender’s Journal}

Mr. Klingender was a mysterious man. We do not know his first name for certain, it might have been Friedrich Wilhelm but Emil is possible too. The only source for his life story is an old business history (Tigerstedt 1940, 1952). ${ }^{1}$ It is probable that he was born in Germany in the 1770s. He might have worked in Frankfurt am Main before migrating to St. Petersburg. At this time, his brother had moved to England where he started a career in business. Klingender worked in several "counting houses", as he calls the merchant houses he worked in, around the Baltic Sea. In late 1838, while living in Vyborg he started his memoirs "to assist my memory." (Remembrances, 163) He kept recalling his journey until October 1839 when de decided to return St. Petersburg after being brushed off by the love of his life, Miss Blanche Beauchant. For an unknown reason, Klingender left his memoirs in Vyborg when he moved to St. Petersburg. His employer', J. F. Hackman jr. kept the book and it is now a part of Hackman's archive in Åbo Akademi manuscript library, where the Hackman family archive is kept in Turku, Finland.

Klingender's memoirs are a unique source; there were not many clerks at his time, living in the northern Baltic, who had had left a personal notebook or journal. Typically, historians have been more interested in successful business managers, autobiographers or well-known diarists' writings more than unknown clerks' notes (Barker 2009). In Russia, not all merchants could read or write and if they could, hardly any of them wrote down their intimate feelings. Instead, a typical merchant or clerk journal was a ledger, filled with incoming and outgoing money and debts (Ransel 2009, xv-xvi). However, in Klingender's memoirs, all these typical elements are missing and hence, we do not know much about his daily life in detail.

Instead of the daily markings of his doings, Klingender's memoirs are a record of his feelings; rather than focusing on business, he pours out his desperate love for Miss Blanche, who had a real-life counterpart in Vyborg. "I could not help thinking of her, and felt that I was pretty deeply in love with her"

1 A business historian Örnulf Tigerstedt has given the name Friedrich Wilhelm, but in some sources, there is a man called Emil Klingender, whose life story resembles F. W. Klingender's. See, e. g. Hessische Biografie ID=8733 Klingender, Jean Frederic. 
(Remembrances, 16). Klingender proposed to Blanche twice but was turned down. Klingender interpreted Blanche's rejection as a sign of his failure to attain the 'hegemonic' masculinity of the period, one in which men gained an independent position as a merchant. He himself, as he wrote, 'had nothing to offer' (“je n'ai rien à offrir") and having reached the age of fifty already 'believed it was too late' (“je croyais qu'il étoit trop tard") (Remembrances, 177) to gain access to this hegemonic identity of an independent, married man and businessowner. That did not stop him from aspiring to such a role, however. Klingender's memoirs resemble those journals and diaries of eighteenth-century British gentlemen, who shared their preoccupations with the costs and benefits of marriage, studied by Amanda Vickery (Vickery 2009, 57). The memoirs resemble also eighteenthcentury Swedish middle-class men's erotic journals studied by Jonas Liliequist (2007). It seems that at that time, a habit of writing erotic memoirs or a personal journal was quite widely spread among the middling sort of men; writing an intimate journal might have been crucial for the masculine ideal. In these journals, men revealed their feelings and emotional distresses, but also boasted about their triumphs with women, creating hegemonic masculinity by subordinating and oppressing women.

Klingender's memoirs are written in English, partly in French. Neither these languages were his native; he spoke German and used German in his daily businesses. It seems that Klingender wanted to practice his language skills, or perhaps he wanted to keep his memoirs private. He encoded names, too. He used the nom de plume David Glöckner when referring to himself as a writer, but he also used the pseudonyms Jonathan Mercour and Ebeneser McReady. These men gathered "at the Tea Time" and told their life stories to each other. By choosing these characters, he constructed an alternative narrative of masculinity, based on a male homosocial world he was used to living in. In most part of the memoirs, Jonathan Mercour reminisced about his journeys and his desperate love for Miss Blanche. Under his pseudonyms, Klingender made sarcastic and malicious comments about the people he knew. For example, when he described one of his employees in Narva, Eduard Sutthoff, he wrote: "Ned Dry, who likewise, was brought up a Scholar, but turned a Merchant, without having any right notions about Commerce, which however he has the good Sense not to pretend to have" (Remembrances, 9). Klingender's memoirs resemble nineteenth-century 'club talk'; gossiping, telling stories and passing anecdotal information as well as making sarcastic comments about people. This 'club talk' may illustrate how gender was created and maintained (Milne-Smith 2009). According to Amy Milne-Smith, "[i]n sharing gossip within the clubs, members created and reaffirmed social and gender boundaries” (Milne-Smith 2009, 87). It was not insignificant with whom gossip was shared. Klingender lacked a close circle of friends in Vyborg - he 
found the local businessmen the least interesting ones ("why a general meeting of gentlemen of Wyburg could not be interesting”) (Remembrances, 114). Instead of mingling with the local men, he chose to build an alternative masculine narrative of three hard-working and intelligent men who were outsiders and had an arrogant attitude towards other men, whom he thought were lazy and not up-todate with their duties: "Man in whatever situation he may be, ought to do his duty, you will find that not one out of a hundred people has even a proper idea of his duties, and that therefore we cannot expect the greater part of them to do it” (Remembrances, 35).

\section{"Selfish as a Merchant Needs to be"}

Klingender's opinion about merchants was cynical and pessimistic, affected by his own failures. However, his view reflected that of the new self-made man type of businessman, which he preferred. He described his employers, timber merchants Herman, Wilhelm, Eduard and Robert Sutthoff as "remarkably close fisted, as the merchants' term it, as selfish as a merchant needs to be [. . .]" and not industrious or stirring, as merchants ought to be (Remembrances, 6). Furthermore, he stated that merchants should not be swindlers but honourable men, independent and capable of taking risks (Remembrances, 22). "The object of all their pains is the hoarding up amassing Money" (Remembrances, 40) was Klingender's final verdict on merchants. This echoes a new entrepreneurial masculinity, based on individual wins and moving away from the old narrative of aristocratic gender norms in which the mark of a man was inherited wealth (Sussman 2012, 91).

When Klingender wrote his memoirs, he was over 50 years old and against his own will, still working as a clerk, which may explain why he was so cynical, sarcastic and even malicious. He understood that the new type of heroic entrepreneur - one who was seeking self-interest, who was industrious and using his money wisely - was something to aspire to, but the local merchant community was still clinging on the old communal values, which were very much in use among the Baltic merchants in the first part of the nineteenthcentury (Keskinen 2018). The disappointments and the discrepancy between his ideals and the reality were written all over the pages of his memoirs. In the 1830s, when Klingender wrote his memoirs, economic difficulties affected the international trading community in Vyborg. At the time, the path to an independent position in the business was not an easy one and Klingender might have felt that he had lost his last chance when the economic crisis hit the markets. 
Among the Baltic merchant community, gendered norms and ideals were based on the presupposition that clerks were young men, who were practicing for their future careers in business. In reality, this potential was available only for few select individuals with a suitable family background or for those with right skills and personality, who happened to be at the right place at the right time. Young men were introduced to the masculine world of trade in their late teens. They worked as clerks and learnt everything they needed to become an independent merchant by apprenticing in merchant houses. This was the common custom all over Europe and dated back to the Middle Ages (Ogilvie 2014; Schulte Beerbühl 2015, 33). The Swedish law of 1734, which was used in Vyborg, stated that a merchant had to have decent training and qualifications to become a merchant. He should have enough skills in mathematics, bookkeeping, and different measurements before he could take his burgher's oath, which all merchants and businessmen had to take according to the law. An apprenticeship lasted seven years, and the young apprentice had to work for four years as a clerk before he could become an independent merchant. If the young man was a son of a merchant, his training time could be reduced since he would have learned the trade while growing up (Vainio-Korhonen 2010, 221-227; Nyberg and Jakobsson 2012, 41-43; Keskinen and Vainio-Korhonen 2018).

The above pictured system excluded women - daughters could not have similar training - and created a masculine realm of business. Furthermore, the system of becoming a burgher-merchant excluded men without proper training and skills, elevating skilled and trained merchants into a hegemonic position. This hegemony was based on the subordination of women and other, less qualified men. In addition to this, the merchant's masculine ideal was based on communal values and the common good - all merchants protected their mutual group interests instead of individual ambitions. If a merchant sought only his personal interest, this could shake the whole community and the business network might collapse. Before the Industrial Revolution, which took place in northern Europe later than in Britain or in continental Europe, business was based on security-seeking monopolies, not profit-seeking individuals (Keskinen 2018; Müller 1998, 20-22). This may have led to an even more exclusive norm of masculinity, which shut out men who tried to shake the community with their far too independent ideas and actions. Access to this community was denied to Klingender, who was inspired by the independent and industrious merchant type which he had learned to appreciate during his journeys to Britain and France. This led him to create an imagined world where he could express his feelings and thoughts without being criticised for his modern thoughts. The alternative narrative of masculinity in Klingender's memoirs was based on imagined independence: "you enjoy one which, after health, is worth 
more than all the rest, - namely independence" (Remembrances, 68), which he actually lacked in real life.

Becoming a proper merchant and burgher, i.e. fulfilling the masculine potential in a town, demanded social and financial capital. A merchant had to have three men who guaranteed him - without the social capital an aspiring merchant was denied access to hegemonic masculinity. The implied norm was that a burgher should be honest and trustworthy, otherwise his fellow burgers would not guarantee him. For a foreigner who had lived an "unsettled life" (Remembrances, 5), proving this was difficult. In other words, Klingender lacked social capital. He was supported and valued as a clerk, but not as an equal merchant. Without money, since the burgher's rights cost, a young man could not become a burgher. This was the block Klingender stumbled over; he lacked the money because he had not saved his earnings; "I spent money freely, as long as I had it” (Remembrances, 5). By writing this, Klingender might have created yet another angle to his alternative narrative of masculinity by choosing not to follow the ideal narrative of the frugal businessman who saves his earnings to invest in his business. Instead, Klingender created a narrative of a spendthrift man, who indulges himself and lives like there is no tomorrow, which does not fit into the ideal model of a businessman of the time but instead reflects the lifestyle of a merry bachelor - or that of a modern, risk-taking, businessman.

\section{"I Should Tell Him to Marry..."}

In accounts of business history, the focus has been on the workplace, not on the home. Men's occupational roles and duties as family men are quite anachronistically separated (Harvey 2009, 521), yet the importance of marriage is recognised (Müller 1998; Sussman 2012, 93; Schulte Beerbühl 2015, 116). However, when studying early nineteenth-century businessmen, home and the domestic environment, their families and wives, were a crucial part of their occupational identity. (Tosh 2005; Keskinen and Vainio-Korhonen 2018, 134) Amanda Vickery has pointed out that "the polish of female company was crucial for the achievement of modern polite manhood" in the late eighteenth- and early nineteenthcentury (Vickery 2009, 198). Men showed their superiority in the choice of a wife who could support their career and could bolster their performance of masculinity. Klingender worked in a homosocial environment but dreamt of marrying and thought that marriage was a man's doom. "If I had a Son, and if he came to ask my advice, I should tell him to marry, as soon as he was so situated as to be able to maintain his wife; - there is no alternative in this 
affair, it is the principal affair in this world, it is what we are here for, it is our doom ..." (Remembrances, 72).

In eighteenth- and nineteenth-century business, marriage was important because the merchant family and community must reproduce. Swedish historian Leos Müller has pointed out that "social reproduction of the family was a basic motivation of any entrepreneurial activity” (Müller 1998, 31-32). Especially for the old communal system, marriages were an important way to renew, expand and stabilise business networks and to collect capital (Keskinen 2019, 79; Müller 1998, 250). This means that being married, staying married and having children was crucial for businessmen and in the world of global business, hegemonic masculinity was intertwined with being a family man. An unmarried merchant could not reach his full potential as a merchant and man, because he could not produce an heir to his business. Furthermore, married men were considered more respectable, reliable and trustworthy, in some cases even morally and economically superior to unmarried men (van Broek 2011, 292, 294).

British historian John Tosh has demonstrated that in nineteenth-century Britain, new 'modern' masculinity was organised around a dual commitment to work and home, giving way to the bourgeois society of the late nineteenth- and early twentieth-century Europe. The nineteenth century was, indeed, crucial for the development of an entrepreneurial, individualistic masculinity which combined a demanding work ethic with the comforts of home (Tosh 2005, 331-332). This dual commitment can be read from the Klingender's journal. In other words, in Klingender's lifetime, hegemonic masculinity in the business world became a narrative of women's absence from the workplace, and men's access to a domestic sphere, where the wisely chosen wife reigned the drawing room (Vickery 2009, 198) even if both of those were not necessarily the day-to-day reality of every family. It seems that the division of duties was gendered in Klingender's social circles, leading him to point out several times that it is men's duty to provide for their families. (Remembrances, 73, 159) In an imagined marital agreement he described his fictional friends' duties: "[I]being the husbands' duty to maintain and protect his wife and family, Mr. Steadymore will steadily work for that purpose, and earn the necessary to provide for their mutual wants, whereas it will be Miss Morelove's province to keep the house and table in good order" (Remembrances, 159).

During Klingender's lifetime, middle-class men became 'bread-winners', exclusively responsible for the family income (Davidoff and Hall 1987, 229-271) and as the above illustrated journal extract points out, this was the model Klingender preferred. There are numerous studies discussing when the separation between work and family lives began. Typically, scholars place it at eighteenth- or nineteenth centuries, when privatisation took place in European 
society (Vickery 2009, 27; Harvey 2009, 521-523; Tosh 1999). It seems that in Klingender's social circles, the separation between the masculine world of business and the feminine realm of home was already the norm.

In large timber export companies, even when they were owned and managed by a woman (only a merchant's widow could do this), the female ownermanager seldom spent her time in the "counting house". As Jarkko Keskinen and Kirsi Vainio-Korhonen have pointed out, in the seventeenth and eighteenth-century, the Swedish Crown revised legislation which led to restrictions on women's participation in family business (Keskinen and Vainio-Korhonen 2018, 135), creating even more gender-specific workplaces and business environments. Hence, the office space in large companies was strongly masculine. Young men were trained in all-male trading houses, they lived with their male colleagues, and after-work socialising was performed in same-sex groups, so it is hardly surprising that women remained mysterious and remote to men in business and this distance was reflected in their private lives and lives of families, too (Tosh 1999).

Then, because (some) men lacked the experience of living their everyday lives beside women, relating to them socially and emotionally was complex for some men. Expressing excessive feelings of love ran counter to norms surrounding the 'right' kind of masculinity. If a man was too deeply in love and affected by romantic emotions, he might have lost his independence and, therefore, his superiority over women. (Liliequist 2007) and become unable to provide for his wife and pursue his career. This was also Klingender's fear: "I should ${ }^{2}$ despise a man who could be completely ruled by a woman!” (Remembrances, 133).

Klingender's sentimental expressions of love did not lead to marriage and so, instead of becoming a breadwinner and representing what could be seen as hegemonic masculinity in his social circle, he turned his life into an alternative narrative of a merry bachelor life and described women despisingly. "I am not fond of the character of women in general, and above all things I hate, and abominate their frivolity" (Remembrances, 50). This negative attitude towards women did not prevent him from dreaming of his beloved Blanche, who was not like other women but wise, talented and witty (Remembrances, 139).

Klingender who was raised and trained in a masculine business environment seem to have been perplexed with women; he knew how to court them but not how to approach them as equals. Nor does he write anything about the life after the wedding ceremony, which he dreamt having with Blanche (Remembrances, 162). In the

2 The crossing-out is by Klingender. 
public discourse, as well as in Klingender's memoirs, questions of whether to marry and when to marry were more important than how to be a good husband or a father (Tosh 1999, 79).

Klingender created a counter-narrative of what could be seen as 'complicit' masculinity, in a context in which the hegemonic norm was deeply rooted in family life. The counter-narrative of a bachelor life, where men could gather together to "have a bit of chitchat together" (Remembrances, 2), is written all over the pages of the memoirs. This narrative does not dismiss domesticity, but rather creates an all-male version of it, which was a refuge from daily drudgery - providing the emotional and psychological support a man needed in his life, (Tosh 1999, 6) through the company of other men. As Karen Harvey points out "[a]n emerging middle-class domesticity did not exclude men; they were a (literally) central part of its constitution” (Harvey 2009, 527). In other words, not only did men-only clubs and associations not preclude family men from also being central to family life - socialising in allmale company at homes could represent a mode of domesticity for those who fell short of the norm, but did not openly disrupt or contest hegemony either, as Klingender's memoirs vividly illustrate.

Klingender remained a bachelor, which was quite typical in the nineteenthcentury business world. Although a marriage was crucial, men married late, because they had to accomplish an independent status and establish their own business before getting married. Hence, there was a strong bachelor culture in the realm of business, which may emerge as men's preference for town pleasures, intellectual male company, 'gay' life, or on the other hand, as devotion to their career, public duties and making profit (Tosh 1999, 173, 175). It seems that there was room for multiple masculinities or diversity within hegemonic masculinity (Connell and Messerschmidt 2005, 835, 845). Hegemonic masculinity might have embraced aspects of bachelor culture while heavily depending on marriage and domesticity. The strong bachelor culture among businessmen therefore helped to enforce hegemonic masculinity. According to Connell and Messerschmidt, hegemonic masculinity became most powerful when there was a group of men who showed 'complicit masculinity'. These men received the benefits of patriarchy without performing a strong masculine dominance (Connell and Messerschmidt 2005, 832). Clerks and unmarried men benefitted from hegemonic masculinity; their place in the business was not threatened by women, since the local practices and legislation shut the doors for most of women. Beside this, 'complicit masculinity' took advantage of hegemonic masculinity which was deeply connected with leading positions in business and the family life - bachelors and clerks did not take responsibility for either of these duties. Instead, they could live quite carefree and happy lives, which 
Klingender recognised in his memoirs: "Riches perhaps would not have made you happier than you are now, my good friend” (Remembrances, 5).

\section{"Mixed with Pride and Vanity Inspired by Wealth"}

Masculinity was embedded locally in specific social environments (Connell and Messerschmidt 2005, 839) and represented by material culture, noticed and illustrated by Klingender as well as scholars studying eighteenth- and nineteenth-century masculinity and the world of trade (Hunt 1996, 4; Vickery 2009, 162). Klingender wrote several times about his visits to his friends' country homes.

"Tuesday, in making visits to some of my friends in the country, first to Mr. Bützow of Terwajocki, which place, by dint of industry, care and, (as some people say) a greater expense than the owners are able to make, is become the finest country seat about Wyburg, thus to Mr. Dannenberg of Kiskila, and lastly to General Etter, of Wainika, who has made great improvements at his country place, so much so, that what cost him perhaps 5000, he now asks 30000 Roubles for" (Remembrances, 137).

These country houses illustrated their owners' success in life - Mr. Bützow being a doctor and Mr. Dannenberg a merchant. Klingender's employers, Sutthoffs in Narva and Hackmans in Vyborg, also had country houses near the towns where they lived (Ijäs 2015). These country houses were purchased with the money the owners had earned in their profession, or with money they had inherited, married or borrowed, or with the money they never had, as Mr. Bützow's case points out. A country house to which one could retire signalled a businessman's success. Middle-class masculinity emulated on the one hand a noble lifestyle with family estates, and on the other hand, created their own standards of material success, which the country houses manifested without a doubt (Hunt 1996, 6).

Klingender did not have a country seat, which was yet another failure; he recollected numerous visits to country houses and what improvements the owners had done, but then, in the evening, he had to withdraw to his small and uncomfortable room where he was required to stay, despite his attempts to demand better quarters (Remembrances, 132). In his memoirs, Klingender describes the rooms he stayed in with few words, feeling sorry for himself for being forced to stay in "a Single room, so low, that, without stretching out your hand much above your head, you could reach the ceiling, and so Narrow, that there was room for two persons only, but for no more" (Remembrances, 4). These spatial arrangements did not encourage married life, but instead, reflected a life of and 
a dedication to work. Single men in the world of business lived modestly, without calling their lodgings home but a quarter. Their masculinity was mainly created and maintained outside residential houses, but in clubs and other public places and rooms (Tosh 1999, 127), which might turn these places into spots where 'complicit masculinity' is enforced and which is discussed later in this chapter.

Hegemonic masculinity is related to ways of representing men's bodies (Connell and Messerschimdt 2005, 851). Visually, materially and bodily exemplifying masculinity in the business were the suit and the outfit. A businessman could typically be recognised from his appearance, which has been a welltailored suit since the late nineteenth-century (Finn 2000, 137-138; Sussman 2012, 82). We do not know what Klingender looked like; he does not refer to his appearance, nor are there any markings about his purchases in the memoirs. The clerks might have worn a brown jacket and black breeches, which was almost like a clerk's uniform before the ready-made suits and changeable white collars took their place in the latter part of the nineteenth century (van Broek 2011, 296). In the early nineteenth-century Europe, almost all men wore a darkcoloured tailcoat, which had replaced the colourful French style coats and embroidered waistcoats, worn by aristocracy and imitated by lower rank men (Snellman, Vajanto and Suomela 2018; Sussman 2012, 82; Finn 2000, 154).

In Klingender's lifetime, men's outfits still clearly expressed and visualised social rank. Especially in nineteenth-century Russia, men of various occupations and ranks, including civilians, had their own uniforms (Ransel 2007, 427; Snellman, Vajanto and Suomela 2018). For example, when J. F. Hackman became the Prussian consul in 1803, he could wear a blue jacket with red labels and white breeches, tailored by a St. Petersburg tailor (Ijäs 2014). Uniforms not only expressed masculine status but also power and bodily strengths; uniforms shaped the male body and a well-fitting tailored uniform was a sharp contrast to a shaggy and baggy clerk's outfit with ink stained sleeves. Especially the uniform, taking inspiration from military uniforms, connected masculinity with war, bodily strength and physical power. Hegemonic masculinity as it was performed by the uniform wearer was therefore not only an abstract construction, but a highly visual and bodily experience.

Impeccable appearance was important; masculinity was connected with honesty, trustworthiness, modesty and high work ethics, all of which the outfit revealed and enforced. Hegemonic masculinity demands constant negotiation with what is fashionable - the outfit or habitus is not a self-reproducing form (Connell and Messerschmidt 2005, 844). The importance of an outfit can be realised when studying men's expenditures on textiles and clothing; men all over Europe, from Britain to Vyborg, spent substantial amounts of money for fabrics and for accessories, and 
discussed the latest fashion and styles (Finn 2000, 140; Ijäs 2014). Klingender was not blind to men's outfits; when he met Colonel Boije on his friend's country estate, he noticed that the Colonel was elegantly dressed, which in Klingender interpretation reflected his military-administrative office: "as elegantly will the Province no doubt be governed" (Remembrances, 151). This is in strong contrast with his employer Sutthoff, who "had a silly appearance [...] mixed with the pride and vanity inspired by wealth" (Remembrances, 130). In the eighteenth- and early nineteenth-century business world, money could not buy taste and style, but 'savoir vivre' was seen as intrinsic and as a result of good breeding. The lack of this denied Klingender access to the polite society (Remembrances, 168), ${ }^{3}$ despite his own efforts to follow fashion and his ability to know when vanity overcomes good taste.

The external expressions of masculinity embraced by the elites were hard and sometimes impossible to reach by outsiders or by lower class men (Ilmakunnas 2017, 243-264). This enforces the fact that there were several masculinities at play (Connell and Messerschmidt 2005, 835), some of which lower class men were unable to reach, and in some cases, they might have developed their own masculine codes, expressed in their appearance, but which Klingender's memoirs do not reveal.

\section{"I have seen Clubbs at Petersburg, in Germany and in England"}

As noted above, the home was not the only important place where masculinity was created, negotiated and revalued. In Klingender's memoirs, he remembers his theatre visits, nights at clubs and his walks in nature and at parks. These activities and performances, such as promenading, 'made men' in every businessand gentlemen society all over Europe and the colonies (White 2006). One of the most iconic places for nineteenth-century masculinity was a gentlemen's club, which was a homosocial but at the same time very exclusive place. The access to a club might have been the ticket to hegemonic masculinity at the time.

Klingender boasted that "I have seen Clubbs [sic] at Petersburg, in Germany and in England, and I have to found them to be much the same everywhere.

3 On 11 September, 1839, Klingender refused to go to his friend's wedding, because the father in law has treated him disrespectfully, hinting that he lacked good breeding and "savoir vivre". 
People [i.e. men] meet to read the Newspapers, to play at Cards or at Billiards, and to converse [. . .]" (Remembrances, 113, see also 27, 127, 138). In the nineteenth century, according to the separate spheres ideology, homes became more and more feminised spaces, even as men remained central to domestic life. Clubs were places where men could escape the responsibilities of domestic life, a place of their own (Black 2012, 16, 19). Gentlemen's clubs were places where masculinity was negotiated, maintained and revaluated; men's 'club talk' was a way to prove one's masculinity. Because talk was an integral part of the gentlemen's clubs, masculinity and gender were created orally, in discourse in a homosocial community (Milne-Smith 2009).

According to Klingender, the club and theatre in Vyborg were places he preferred to avoid - there, the insipid local society gathered and gossiped. Yet again, Klingender chose an alternative route, which he created by staying alone in his rooms. Men in Vyborg Club did not have the masculine characteristics Klingender preferred - Vyborg club men tended to gossip instead of discussing with each other, and they were not as learned as Klingender would have wished for (Remembrances, 114). Klingender could have visited the club if he had wanted to, but chose not to. Klingender expressed 'complicit masculinity' - he benefitted from hegemonic masculinity of the club men by gaining access to the club which was not open to all men, and knew the language codes of the club talk, but he chose to step aside, perhaps because his subordinate position became evident in the club. Constructed largely through social practice and sociability, both hegemonic and complicit masculinity would be more obvious in such a place (Connell and Messerschimdt 2005, 832).

For Klingender, because he was not able or willing to enter the gentlemen's club in Vyborg, he replaced going to the club by writing his memoirs, remembering old discussions and filling the pages with 'club talk'. 'Club talk' was a crucial part of this process of creating the right kind of middle-class masculinity. This talk was mixed with false rumours and frivolity; being able to tell a good story was an important way to demonstrate one's status as a gentleman (Gordon 2006, 38-39; Milne-Smith 2009, 93). All the aspects of 'club talk' are well represented in Klingender's memoirs; he gossips, tells stories and points out his own virtues, turning his bad habits and misfortunes in his career to his personal triumphs. The masculine persona he created through this written 'club talk' was perhaps so deeply rooted in this way of talking that he did not notice the paradox of being guilty of similar gossiping and bragging which he did not appreciate in other men's discussions at the Vyborg Club. The use of 'club talk' also reveals that Klingender sought hegemonic masculinity and that family and independence at business were not the only aspects of hegemonic masculinity he aimed at. Despite avoiding 
Vyborg's clubs, he enacted its practices in his diary, where he attempted to both perform and challenge aspects of the ideal of hegemonic masculinity simultaneously.

\section{Making it Like a Man?}

Klingender's life story reveals a man whose real name remains unknown. He was one of the thousands of paid workers who enabled the transnational trade in the nineteenth-century Europe, but who did not leave their names into business histories. Typically, the focus has been on the leading figures and those who performed hegemonic masculinity. Hegemonic masculinity, however, would not have been possible without complicit and subordinate men. Gender history has discussed women quite extensively, representing one subordinate group in the realm of business, but less attention has been paid to non-leading men in the world of business. Their careers might reveal new perspectives on the history of business, work, career and gender.

Klingender's memoirs follow a similar pattern as that of their British and Swedish counterparts, revealing the emotional journey of a middling sort man. Beside the affectional story of a missed love and marriage, the memoirs illustrate how hegemonic masculinity, in the business world, changes in the early nineteenth century. At the beginning of the century, community values reign supreme and a 'career' is defined as gaining stature in the community. This career is strongly connected to family values, being a merchant's son, then being a husband and father and hence, reproducing the community. By the end of the century, the career-model becomes that of the 'self-made man' whose individual qualities such as industrious mindset and willingness to take risks mark him out as a good businessman. Klingender lived through the process of change, and therefore he does not fit into either model. He was geographically mobile, a bachelor who imagined himself - perhaps wrongly - to be capable of being a businessman and husband. He shared some of the morals of the old model - perhaps due to his Calvinist upbringing - whilst also being dismissive of some of the old community values and instead, promoted a new industrious and risk-taking type of businessman. In other words, what he actually practiced was 'complicit masculinity': he shared the ambitions that were typical of the 'old' hegemonic masculinity and effectively supported this ideal by embracing club-talk and caring deeply about marriage and family life - without actually reaching hegemonic status himself. But he also seems to have appreciated a 
modern shift toward a more individualistic model of business, indicating that his relation to the extant model of hegemonic masculinity was complex.

Klingender's memoirs reveal that early nineteenth-century business world masculinity was socially diverse; there were business families lead by independent merchant-burghers and then there were clerks - typically young men who did the monotonous daily work of keeping books and writing letters. Hence, it would be better to discuss masculinities in the plural. The latter group - unmarried men - might have developed a specific lifestyle, diverged from the conventional norm for businessmen which was intertwined with family life and which was important for the 'old' masculinity. In a situation when clerks were denied performing hegemonic masculinity, they turned away creating their own codes where boisterous behaviour, drinking, gossiping, and to some extent, misogynist attitudes were praised. This may lead to toxic masculinity, separating different groups of men - married and unmarried, young and old, those with higher moral or religious beliefs from those with more secular worldviews - from each other, which would eventually affect the society at the whole. The 'new' type of masculinity, emerging in the latter part of the nineteenth century, might have been built upon the bachelor type of masculinity. The new self-made man type of masculinity preferred risk-taking and individualistic thinking; at the time, the home and family life were not necessary prerequisites for businessmen. It is highly possible that the new business elite rose from the group of young boisterous clerks who did not find their place among the old businessmen. This meant also that the preferred masculinity changed; then, virility, homosocial behaviour and a clear separation of work and home became dominant features of masculinity.

Masculinity was not only a narrative, created by 'club talk' or by other older narratives which encouraged family life, but a lived experience. Hegemonic masculinity among the businessmen was linked with the material surroundings that supported their power position. Well-to-do men had their country houses, flamboyant uniforms and outfits while Klingender and clerks like him had to live in small backoffice rooms and to wear ink-stained clothes. Although hegemonic masculinity was a spatial, visual and bodily experience - how a man lived and dressed affected his experiences of everyday life - it was also a conscious reconstruction. When a man was aspiring to hegemony, or when he reached it, the standard of living and how he dressed was not insignificant but a conscious choice, based on society's demands and cultural codes, to demonstrate one's wealth and status. It was not insignificant how men lived, dressed and how they spent their time at work and at leisure, because it created dominance - spatial, bodily and cultural - over other men and women. This dominance may turn into a special business culture where a man's career and success in it affect his life and the lives of his 
family members, associates, friends and the society at large. Career failure was therefore not only a personal temporarily misfortune but reveals his incapability of being a man. This might be the reason why Klingender's memoir had such a depressed undertone.

\section{Sources}

Åbo Akademis Library (ÅA), Handelshuset Hackman, HH 33, Remembrances . . . Hessen Landesgeschichtliches Informationssystem, Hessische Biografie, Projekt "Collegium Carolinum": Professoren: Klingender, Jean Frederic. Link to the online source: https:// www.lagis-hessen.de/de/subjects/drec/mode/projects/projectld/cc/id/8733/current/ 14/cIndex/0/sn/bio (Accessed March 30, 2020).

\section{References}

Barker, Hannah. 2009. “A Grocer's Tale: Gender, Family and Class in Early Nineteenth-Century Manchester." Gender \& History 21(2): 340-357.

Black, Barbara J. 2012. A Room of His Own: A Literary-Cultural Study of Victorian Clubland. Athens: Ohio University Press.

Bruni, Attila Silvia Gherardi, and Barbara Poggio. 2004. "Entrepreneur-mentality, gender and the study of women entrepreneurs." Journal of Organizational Change Management 17(3): 256-268.

Connell, Raewyn, and James W. Messerschmidt. 2005. "Hegemonic Masculinity: Rethinking the Concept." Gender \& Society 19(6): 829-859.

Craig, Beatrice Robert Beachy, and Alastair Owens. 2006. "Introduction." In Women, Business and Finance in Nineteenth-Century Europe. Rethinking Separate Spheres, edited by Robert Beachy, Béatrice Craig, and Alastair Owens, 1-19. Oxford: Berg.

Davidoff, Leonore, and Catherine Hall. 1987. Family Fortunes: Men and Women of the English Middle Class, 1780-1850. London: Hutchinson.

Finn, Margot. 2000. “Men's things: masculine possession in the consumer revolution." Social History 25(2): 133-155.

Gordon, Jan B. 2006. Gossip and Subversion in the Nineteenth-Century Novel: Echo Economies. New York: St. Martin's Press.

Hamilton, Eleanor. 2013. “The Discourse of Entrepreneurial Masculinities (and Femininities).” Entrepreneurship \& Regional Development 25 (1-2): 90-99.

Harvey, Karen. 2009. "Men Making Home: Masculinity and Domesticity in Eighteenth-Century Britain.” Gender \& History 21(3): 520-540.

Hassan Jansson, Karin, Rosemarie Fiebranz, and Ann-Catrin Östman. 2017. "Constitutive Tasks. Performances of Hierarchy and Identity”. In Making a Living, Making a Difference. Gender and Work in Early Modern European Society, edited by Maria Ågren, 127-158. Oxford: Oxford University Press. 
Hunt, Margaret. 1996. The Middling Sort: Commerce, Gender, and the Family in England, 1680-1780. Berkeley: University of California Press.

ljäs, Ulla. 2014. "Favourites of Fortune: The Luxury Consumption of the Hackmans of Vyborg, 1790-1825." In Luxury and Gender in European Towns, 1700-1914, edited by Deborah Simonton, Marjo Kaartinen, and Anne Montenach, 190-205. Routledge Studies in Cultural History. London and New York: Routledge.

ljäs, Ulla. 2015. Talo, kartano, puutarha. Kauppahuoneen omistaja Marie Hackman ja hänen kulutusvalintansa varhaismodernissa Viipurissa. Turku: Turun yliopisto.

Ilmakunnas, Johanna. 2017. "French Fashions: Aspects of Elite Lifestyle in Eighteenth-Century Sweden." In A Taste for Luxury in Early Modern Europe: Display, Acquisition and Boundaries, edited by Johanna Ilmakunnas, and Jon Stobart, 243-264. London and New York: Bloomsbury.

Keskinen, Jarkko. 2019. "Cooperative Competition: Business Culture in the Finnish Merchant Community in the First Half of the 19th Century." Scandinavian Journal of History, 44(3): 287-309.

Keskinen, Jarkko, and Kirsi Vainio-Korhonen. 2018. "Statutory Invisibility: Urban Business Women's Legal and Political Rights”. In Women in Business Families from Past to Present, edited by Jarna Heinonen, and Kirsi Vainio-Korhonen, 134-152. London and New York: Routledge.

Kwolek-Folland, Angel. 2001. "Gender and business history." Enterprise \& Society 2(1): 1-10.

Lahtinen, Anu. 2018. "Tough Times, Tough Measures. Widows as Heroic Entrepreneurs." In Women in Business Families. From Past to Present, edited by Jarna Heinonen, and Kirsi Vainio-Korhonen, 35-46. Routledge Advances in Management and Business Studies. New York and London: Routledge.

Liliequist, Jonas. 2007. "Masculinity and Virility - Representations of Male Sexuality in Eighteenth-Century Sweden.” In The Trouble With Ribs: Women, Men and Gender in Early Modern Europe, edited by Anu Korhonen, and Kate Lowe. COLLeGIUM. Studies Across Disciplines in the Humanities and Social Sciences. Vol. 2. http://www.helsinki.fi/colle gium/journal/volumes/volume_2/index.htm (accessed March 30, 2020)

Milne-Smith, Anne. 2009. "Club Talk: Gossip, Masculinity and Oral Communities in Late Nineteenth-Century London.” Gender \& History 21(1)(April): 86-106.

Müller, Leos. 1998. The Merchant Houses of Stockholm, c. 1640-1800. A Comparative Study of Early-Modern Entrepreneurial Behaviour. Uppsala University Press, Uppsala.

Nyberg, Klas, and Håkan Jakobsson. 2012. Storköpmän som samhällskraft: Borgerskap och Grosshandelssocietet i Stockholm. Informationsförlaget, Stockholm.

Ogilvie, Sheilagh. 2014. The Economics of Guilds. The Journal of Economic Perspectives 28(4): 169-192.

Ojala, Jari, and Petri Karonen. 2006. "Finnish Business: rooted in social capital over the centuries." In The Road to Prosperity: An Economic History of Finland, edited by Jari Ojala, Jari Eloranta, Jukka Jalava, and Rita Asplund, 93-125. Helsinki: Suomalaisen Kirjallisuuden Seura.

Ransel, David L. 2007. "Russian Merchants: Citizenship and Identity." In Eighteenth-Century Russia. Society, Culture, Economy. Papers from the VII International Conference of the Study Group on Eighteenth-Century Russia, edited by Roger Bartlett, and Gabriela Lehmann-Carli, 417-428. Berlin: Lit Verlag.

Ransel, David L. 2009. A Russian Merchant's Tale. The Life and Adventures of Ivan Alekseevich Tolchënov, Based on His Diary. Bloomington and Indianapolis: Indiana University Press. 
Schulte Beerbühl, Margrit. 2015. The Forgotten Majority. German Merchants in London, Naturalization, and Global Trade, 1660-1815. New York, Oxford: Berghahn.

Simonton, Deborah. 2018. “'All the Days of Their Lives.' Women, Business, and Family.” In Women in Business Families. From Past to Present, edited by Jarna Heinonen, and Kirsi Vainio-Korhonen, 111-133. Routledge Advances in Management and Business Studies. New York and London: Routledge.

Snellman, Alex, Krista Vajanto, and Jenni Suomela. 2018. "The Professorial Uniform of Elias Lönnrot: Russian Imperial Materiality in Finland.” Artefactum No 9.

Sussman, Herbert L. 2012. Masculine Identities: The History and Meanings of Manliness. Santa Barbara, Denver and Oxford: Praeger Press.

Tigerstedt, Örnulf. 1940. Kauppahuone Hackman. Erään vanhan Wiipurin kauppiassuvun vaiheet 1790-1879. I osa. Helsinki: Otava.

Tigerstedt, Örnulf. 1952. Kauppahuone Hackman. Erään vanhan Wiipurin kauppiassuvun vaiheet 1790-1879. II osa. Helsinki: Otava.

Tosh, John. 1999. A Man's Place. Masculinity and the Middle-Class Home in Victorian England. New Haven and London: Yale University Press.

Tosh, John. 2005. "Masculinities in an Industrializing Society: Britain, 1800-1914." Journal of British Studies 44(2): 330-342.

Vainio-Korhonen, Kirsi. 2010. "Kaupan ja käsityön ammattikasvatus." In Huoneentaulun maailma: kasvatus ja koulutus Suomessa keskiajalta 1860-luvulle, edited by Jussi Hanska, Kirsi Vainio-Korhonen, and Pauli Kettunen, 231-255. Helsinki: Suomalaisen Kirjallisuuden Seura.

van Broek, Diane. 2011. "Strapping, as well as numerate: Occupational identity, masculinity and the aesthetics of nineteenth-century banking." Business History 53(3): 289-301.

Vickery, Amanda. 2009. Behind Closed Doors. At Home in Georgian England. New Haven and London: Yale University Press.

White, Cameron. 2006. "Promenading and Picnicking: The Performance of Middle-class Masculinity in Nineteenth-Century Sydney." Journal of Australian Studies 89: 27-40. 